\title{
Jakten på risikanter
}

\author{
Behandlingen av livsstilsrelatert sykdom beslaglegger en økende del av tilgjengelige helse- og samfunns- \\ ressurser. I hvilken grad skal vi bruke befolkningsrettede strategier for å motvirke dette, og hvor mye skal \\ vi basere på individuelt endringsarbeid? I samhandlingsreformen legger man opp til en større satsing \\ på forebygging. Fastlegen er tiltenkt rollen med å identifisere risikanter. Er dette en riktig satsing?
}

\section{Eirik Abildsnes}

eabil@broadpark.no

Institutt for samfunnsmedisinske fag

Universitetet i Bergen

Kalfarveien 31

5018 Bergen

og

Elvebredden legesenter

Kristiansand

Den engelske epidemiologen Geoffrey Rose påpekte i 1985 at bare $\mathrm{i}$ befolkningsstrategier søker man å fjerne underliggende årsaker til sykdom, mens man i høyrisikostrategier søker å beskytte dem med forhøyet risiko (1). Høyrisikostrategier kan gi god kostnad-nytte-effekt når risikoen er skjevt fordelt i en befolkning. Ofte benytter man screening for å identifisere individer med forhøyet risiko. Imidlertid er det de med minst risiko som i størst grad slutter opp om screening. Å gå fra å føle seg frisk til å bli definert som risikant, kan påvirke opplevd helse negativt (2). Også i populasjoner med forhøyet risiko for sykdom kan absolutt risiko for den enkelte være lav. Når vi ser flere risikofaktorer i sammenheng, er det større sjanse for å finne de med høyest risiko, men samtidig vil flere få påvist litt økt risiko.

Det er et stort og voksende marked for individuell kartlegging av helsetilstand og risiko for sykdom. Fastlegen får mange slike bestillinger. Både leger og pasienter har vansker med å forstå hva risiko innebærer (3). Da kan en risikoutredning få utilsiktede konsekvenser, som å gi livslang behandling og bekymring til mennesker med svært lav absolutt risiko. Økt søkelys på undersøkelse og oppfølging av risikanter vil med begrensede helseressurser nødvendigvis føre til en forskyvning i ressursbruken - fra de syke til de friske, og til helsevesenet fra andre samfunnssektorer. Det er også et etisk dilemma i hvilken grad det er rett å introdusere risikokartlegging for dem som ikke selv ber om en slik avklaring (2).

\section{Sosiale gradienter i helse}

Levevaner er forankret i identitet, sosial bakgrunn og rammer for tilværelsen. Hva man oppfatter som normalt eller helseskadelig, er forskjellig i ulike befolkningsgrupper, mellom kulturer og kjønn og over tid. Det er ikke gitt at lege og pasient har samme vurdering av hva som er en ønskelig livsstil, men det må være en målsetting for kommunikasjonsklimaet at de skal kunne reflektere over dette sammen. Å gjøre endringer som bryter med inngrodde vaner og sosiale rammer for livet, kan oppleves som belastende. Fordelingen av livsstilsrelatert sykdom i befolkningen følger i stor grad sosiale gradienter, og forskjellene $\mathrm{i}$ helsetilstand mellom ulike sosiale grupper $ø$ ker (4). Å vektlegge individuell frihet og ansvar for egen helse, fremfor befolkningsrettede tiltak, kan bidra til å øke sosiale ulikheter i helsen (5).

\section{Virkemidler}

Virkemidlene som man benytter i befolkningsrettet arbeid, er transparente, og dermed gjenstand for gransking og kritikk. Informasjonskampanjer er med hensikt utformet som skremselspropaganda; røyking dreper! Vi vet mindre om hva som skjer i fortrolige samtaler mellom lege og pasient - når legen skal ivareta sitt samfunnsoppdrag som helseopplyser i egen pasientpopulasjon. Bruker man de samme retoriske grepene som i befolkningsrettet helseinformasjon, i en relasjon preget av asymmetrisk maktfordeling? Eller følger legen kliniske retningslinjer hvor man anbefaler en pasientsentrert tilnærming?

\section{Helsemodeller}

\section{og livsstilsrelatert sykdom}

Hva skal vi regne som livsstilsrelatert sykdom? For mange sykdommer vi tradisjonelt omtaler som livsstilssykdommer, er årsakene sammensatte. Det blir da urimelig ensidig å vektlegge levesettet hos den enkelte som hovedårsaken. Forståelse av begrepene sykdom og helse er med på å bestemme hvordan helsepersonell forholder seg til livsstilsrelatert sykdom og atferdsendring.
I den biomedisinske helsemodellen forstår man helse som fravær av sykdom, og sykdom som resultat av en påvirkning av skadelig agens, det være seg mikrober, genetikk eller sosiale forhold. I denne modellen setter man klare grenser for hva helsevesenet skal se på som sitt arbeidsfelt. Ved sosialmedisinens fremvekst ga man medisinen en politisk rolle, som leverandør av epidemiologisk kunnskap om sammenhenger mellom sosiale forhold og helse.

En videre definisjon av begrepet helse kan medvirke til en ekspansiv medisin hvor vi, godt hjulpet av nye diagnostiske muligheter, farmasøytisk industri og økonomisk motiverte aktører i helsetjenesten, omdefinerer biologisk variasjon, naturlige livshendelser og funksjonsforstyrrelser til diagnoser med krav på utredning, behandling og sosiale rettigheter.

I folkehelsearbeidet vektlegger man et salutogenetisk helseperspektiv med søkelys på tiltak som styrker mestringsevnen og mestringsforventningen. Dette perspektivet dominerer ikke helsetjenestens syn på helse, da helsetjenestens primære oppgave er å diagnostisere og behandle sykdom altså et patogenetisk perspektiv.

I den politiske helsemodellen fokuserer man på frigjøring fra profesjonelle eksperter og bygger på myndiggjøring av den enkelte (empowerment). I denne modellen forener man et liberalistisk perspektiv, med ønske om høy grad av individuell frihet og ansvar, med et folkelig krav til frigjøring fra ekspertenes dominans. Man legger i betydelig grad definisjonsmakt og ansvar hos den enkelte, mer enn hos helseeksperten.

Kvalitativ forskning i en fenomenologisk vitenskapstradisjon har gitt oss kunnskap om hvordan mennesker vurderer hva som betyr noe for helserelatert livskvalitet i en folkelig helsemodell. Helse blir med dette blikket en kontekstavhengig, individuell størrelse, preget av individuelle forutsetninger, omgivelser og levd liv. Denne folkelige helsemodellen representerer en protest mot objektivering og frihetsbegrensning. Hva et menneske definerer som helse, vil kunne variere gjennom et livsløp og være forskjellig til ulike tider. Den folkelige for- 


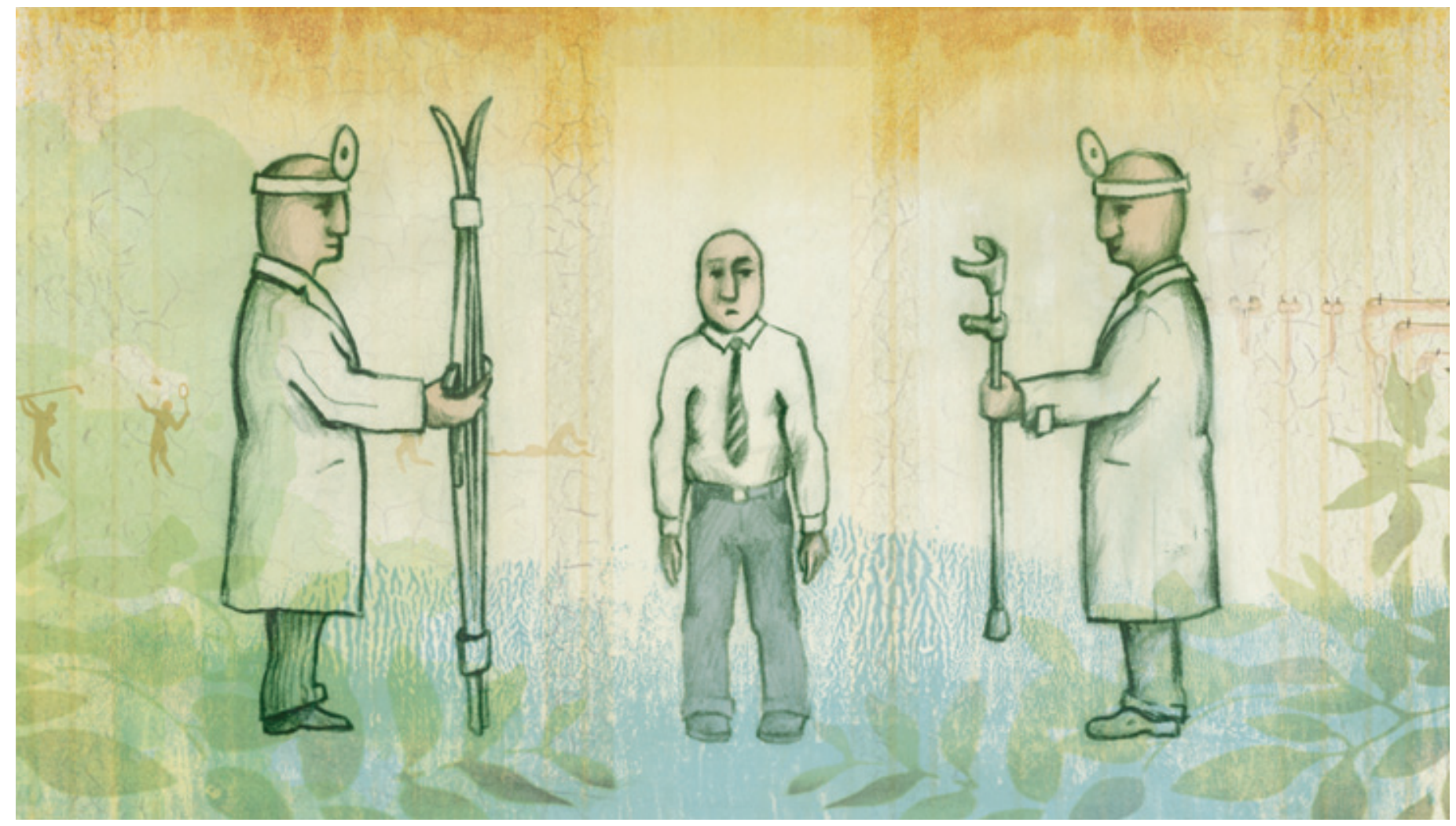

ståelsen av helse har vært viktig i utviklingen av den pasientsentrerte medisinen. Helse og sykdom hos den enkelte ser man her på som et produkt av biologi (som genetisk utrusting), atferdsfaktorer (som livsstil) og sosiale forhold (som fattigdom), og tar inn i seg perspektiver fra flere helsemodeller.

\section{Helsevesenets betydning for helsen} I stortingsmelding nr. 47 (2008-2009) og påfølgende lovforslag signaliserer man en styrking av det forebyggende helsearbeidet i kommunene (6). I meldingen foreslår man befolkningsrettede tiltak, som å oppnå lokal epidemiologisk oversikt, ha et forebyggende og helsefremmende perspektiv i planarbeidet og styrking av samfunnsmedisin og miljørettet helsevern. Man skal også satse på individ- og grupperettede tiltak. Det inkluderer kommunale lærings- og mestringstilbud for livsstilssykdom og styrking av skolehelsetjenesten. Politikerne har foreslått lavterskeltilbud for å stimulere til økt fysisk aktivitet, mindre røyking og sunnere kosthold. Fastlegen er tiltenkt en rolle med særlig ansvar for å identifisere risikanter, gi individrettet veiledning og oppfølging, samt å koordinere den medisinske oppfølgingen av pasientene. Oppdragets formulering reflekterer en betydelig tiltro til helsevesenets evne til å forebygge og endre helseskadelige levevaner i befolkningen.

Aaron Wildavsky har pekt på at bare $10 \%$ av folks helse er noe helsetjenesten kan gjøre noe med, mens $90 \%$ avgjøres av generelle livsvilkår og den enkeltes livsstil
(7). Dette reflekteres ikke i helsetjenestens kamp for sin del av samfunnets samlede ressurser, og heller ikke i stortingsmelding nr. 47. I helsetjenesten kjemper man på det enkelte fagfelt, med gode hensikter, om oppmerksomhet og ressurser til egen virksomhet. Et helhetlig, forebyggende samfunnsperspektiv er lite fremtredende. Står da helsevesenets evne til å ta seg av forebygging i stil med viljen?

\section{Kontroll over virkemidlene}

Befolkningsrettede og grupperettede tiltak iverksetter man som et resultat av en prosess der faglige fremstillinger er underlagt demokratisk kontroll, ved at de danner bakgrunn for politiske beslutninger. Slik sikrer man åpenhet når det innføres begrensninger $i$ den enkeltes eller gruppers rettigheter og frihet for å hindre sykdom, skade eller uhelse. Ekspertens råd er underlagt demokratisk kontroll. Politikernes vilje til å innskrenke den enkeltes eller gruppers frihet og ansvar er ikke veldig stor. Det er mindre kontroversielt å la hver enkelt «være sin egen helseminister». Viljen til å ta i bruk kollektive virkemidler vil avhenge av i hvilken grad ytre trusler, for eksempel epidemier, truer en befolkning. Befolkningsrettede tiltak kan ha stor effekt. Noen tiltak kan være svært kostbare for fellesskapet, som å bygge trafikksikre veier. Andre tiltak kan være svært rimelige, som regulering av tilgang på tobakk og alkohol.

Mange grupper av helsepersonell arbeider med individrettede tiltak, men de fleste som frykter sykdom eller er blitt syke, kontakter sin fastlege. Oftest er det pasienten som oppsøker legen med en opplevd helserelatert problemstilling, ikke omvendt. Arbeid med livsstilsrelatert sykdom er dels initiert av pasienten selv, men også som opportunistisk handling når legen opplever en sammenheng mellom pasientens helsetilstand eller risiko og livsstil. Det er utarbeidet kliniske retningslinjer for slikt arbeid, men det er ingen kontroll over hvilke virkemidler som man tar i bruk $\mathrm{i}$ individuelt endringsarbeid.

\section{Hvordan gi god individuell livsstilsveiledning?}

Det er betydelige forventninger til fastlegens rolle i forebyggingen av livsstilsrelatert sykdom. Han/hun vil ha en nøkkelfunksjon som guide i et uoverskuelig marked, som betrodd rådgiver og inspirator. Leger røyker ikke, spiser sunt og har ofte gode, sosiale nettverk, og opptil flere løper Birkebeineren. Hvilke forutsetninger kan da en lege ha for å endre pasientenes helseskadelige livsstil? Pasientene møter til konsultasjonen med ulike forutsetninger, ønsker, bekymringer, gode og dårlige erfaringer. Dette gjelder erfaringer fra helsevesenet, fra tidligere forsøk på å endre livsstilen, og fra selve livet. Vi kan tenke at en pasientsentrert tilnærming, og å gi pasienten medansvar i tiltaksfasen, vil kunne gi gode resultater. Pasientsentrert kommunikasjon gir større pasienttilfredshet med behandlingen, men det er vanskeligere å påvise endret helseatferd hos pasientene. Legene fokuserer fortsatt lite på pasientenes ressurser (8). 


\section{Usynlig deltaker i konsultasjonen?} Man har reist kritikk mot å bruke konsultasjonen hos fastlegen som en arena for krefter som ønsker at legen skal drive opportunistisk livsstilsendringsarbeid (9). Det er flere som kan spille rollen som usynlig tredje person til stede i konsultasjonen. Helsedirektoratet, helsepolitiske aktører, fagmedisinske miljøer og kliniske retningslinjer bidrar alle til å minne fastlegen om sitt samfunnsoppdrag som livsstilsveileder. Det må så være fastlegens forpliktelse å vekte dette oppdraget opp mot det mandatet som er gitt av pasienten, og å velge sine kommunikasjonsverktøy med omhu. Noen tåler og ønsker røff formidling av risiko, en oppvekking som, formidlet på en empatisk måte, kanskje kan initiere endring. Mennesker med dårlig mestringsforventning kan derimot oppleve tilsvarende fremstøt som krenkelser, som genererer motstand mot endring og ødelegger den tilliten som er bærebjelken i relasjonen mellom lege og pasient.

\section{Arbeidsfordeling}

Rose konkluderte i 1985 med at det var behov for både befolkningsrettede og individuelle tiltak, og at de to strategiene i liten grad sto i motsetning til hverandre. Han poengterte imidlertid at det kun er befolk- ningsrettede tiltak som retter seg mot selve årsaken til uhelse, og at for stort søkelys på individrettede tiltak kan være uheldig. Forslaget til ny folkehelselov pålegger kommunene å utarbeide oppdaterte oversikter over lokale, epidemiologiske utfordringer, og å sette i verk tiltak. Det kan bli et viktig verktøy i arbeidet for å bedre folkehelsen.

Intensivert jakt på den enkelte risikanten, i regi av fastlegen, vil utløse mange bekymringer, prøver, resepter og henvisninger til spesialisthelsetjenesten.. En slik prioritering vil også kunne bidra til mer sosial ulikhet i helse. Forholdet mellom lege og pasient er preget av asymmetrisk maktfordeling, sårbarhet og tillit (10). En forsterkning av fastlegens oppdrag som Helse- og omsorgsdepartementets forlengede arm, vil være et sjansespill. Det kan utløse mistillit og redusere lege-pasient-forholdets relasjonelle kapital. Fastlegen kan likevel gjøre et viktig arbeid med å forebygge og behandle livsstilsrelatert sykdom. Lokale, epidemiologiske oversikter og gode lavterskeltiltak i kommunene kan her være nyttige verktøy. Vi bør også søke å ivareta et folkehelsepespektiv i kommunenes planarbeid.

Oppgitte interessekonflikter: Ingen
Litteratur

1. Rose G. Sick individuals and sick populations. Int J Epidemiol 1985; 14: 32-8.

2. Getz L, Sigurdsson JA, Hetlevik I. Is opportunistic disease prevention in the consultation ethically justifiable? BMJ 2003; 327: 498-500

3. Halvorsen PA, Kristiansen IS, Aasland $O G$ et al. Medical doctors' perception of the «number needed to treat» (NNT). A survey of doctors recommendations for two therapies with different NNT. Scand J Prim Health Care 2003; 21: 162-6.

4. Nasjonalt folkehelseinstitutt. Folkehelserapport 2010. Helsetilstanden i Norge. Oslo: Nasjonalt folkehelseinstitutt, 2010

5. Doyle YG, Furey A, Flowers J. Sick individuals and sick populations: 20 years later. J Epidemiol Community Health 2006; 60: 396-8

6. Helse- og omsorgsdepartementet. St. meld. nr. 47 (2008-2009). Samhandlingsreformen. Rett behandling - på rett sted - til rett tid.

7. Wildavsky A. Doing better and feeling worse: the political pathology of health policy. Daedalus 1977 105-23.

8. Mjaaland TA, Finset A. Frequency of GP communication addressing the patient's resources and coping strategies in medical interviews: a videobased observational study. BMC Fam Pract 2009; 10: 49.

9. Guassora AD, Tulinius AC. Keeping morality out and the GP in. Consultations in Danish general practice as a context for smoking cessation advice. Patient Educ Couns 2008; 73: 28-35.

10. Skirbekk H. Negotiated or taken-for-granted trust? Explicit and implicit interpretations of trust in a medical setting. Med Health Care Philos 2009 12:3-7.

Manuskriptet ble mottatt 21.8. 2010, første revisjon innsendt 18.11. 2010, godkjent 16.12. 2010. Medisinsk redaktør Jon Amund Kyte. 